\title{
高炬スラグ高含有セメントの水和と強度に及ぼす 高炉スラグの化学組成の影響
}

\author{
二戸信和 ${ }^{* 1}$ 植田由紀子 ${ }^{* 2}$ 松澤一輝 ${ }^{* 2}$ 坂井悦郎 ${ }^{* 2}$
}

*1 株式会社デイ・シイ 技術センター( テ 210-0854 神奈川県川崎市川崎区浅野町 1-17)

*2 東京工業大学 物質理工学院材料系 (テ152-8552 東京都目黒区大岡山 2-12-1)

\begin{abstract}
要旨：高炉スラグ微粉末(BFS)の化学組成や粉末度が活性度指数や高炉スラグ高含有セメント (HVBFSC) の水和や強度に及ぼす影響を検討した。BFS の活性度指数や HVBFSC の強度や水和には BFS の化学組 成の影響が大きく、粉末度によって活性度指数を増加するには限界がある。JIS の塩基度が同じでも活性 度指数や HVBFSC の水和や強度が異なるものもある。 $\mathrm{TiO}_{2}$ や $\mathrm{MnO}$ を考慮した塩基度は、いずれも活 性度指数や HVBFSC の水和の傾向まで推察することは難しいが、強度や水和特性が低いものを見分ける ためには有用である。また、HVBFSC の水和初期のカルシウムアルミネート系水和物はエトリンガイト (AFt)であるが、活性度指数の高い BFS を用いるとモノサルフェート $(\mathrm{AFm})$ の生成が増加した。
\end{abstract}

キーワード：高炉スラグ高含有セメント、活性度指数、水和特性、化学組成、粉末度、塩基度、 $\mathrm{TiO}_{2}$ 、 $\mathrm{MnO}$

\section{1.はじめに}

高炉セメントは $\mathrm{CO}_{2}$ 削減対策として有用な材料であ り、特に高炉セメント C 種のような高炉スラグ高含有 セメント(HVBFSC)の利用は、大幅な $\mathrm{CO}_{2}$ 削隇対策が 期待できる。現在、高炉セメントとしては高炉スラグ (BFS) 混合量が 40 \% 程度の高炉セメント B 種が一般 に利用されており、日本では 2018 年でセメント生産量 の $21 \%$ 程度を占めている。2050 年に現状の $\mathrm{CO}_{2}$ 排出 量の 80 \% 削減のためには、欧州セメント産業の戦略 ${ }^{1)}$ ではカーボンキャプチャーなどの技術革新はもちろん必 要であるが、セメントのクリンカーファクターを低下 させる混合セメントの利用も重要とされている。特に $\mathrm{CO}_{2}$ 排出量の少ない高炉セメント $\mathrm{C}$ 種に属するような HVBFSC などの利用は重要となる。

HVBFSC に関しては、既に筆者らは養生温度、セメ ント量、無水セッコウあるいは石灰石微粉末の影響など を詳細に検討した2,3)。その際、普通ポルトランドセメ ント (OPC)：BFS：無水セッコウの比率は質量で 30 : $65: 5$ を基本とした。主要な水和生成物はケイ酸カルシ ウム水和物 $(\mathrm{C}-\mathrm{S}-\mathrm{H})$ 、水酸化カルシウム $(\mathrm{CH})$ 押よびエ トリンガイト $(\mathrm{AFt})$ であること、収縮特性などの観点か ら無水セッコウの利用による AFt の生成が重要である ことを指摘しだ)。また、HVBFSC に対する各種の添 加剤の作用も検討した。亜硝酸カルシウム $\left(\mathrm{Ca}\left(\mathrm{NO}_{2}\right)_{2}\right)$ を添加すると、OPC や高炉スラグの水和促進により、 HVBFSC の初期強度発現性が改善されることを報告し ている4)。さらにジエタノールイソプロパノールアミン (DEIPA)の影響や亜硝酸カルシウムとの併用効果につ
いても検討した。両者を併用すると BFS の反応促進に よる初期の強度増進とエーライトの長期の反応率の増加 による長期強度増進も期待される5)。

しかし、高炉セメント B 種の性質に及ぼす BFS の化 学組成や粉末度の影響について多くの検討がなされてい るが、HVBFSC の性質に及ぼす検討は十分とは言い難 い。HVBFSCではBFS混合量が $60 〜 70 \%$ を占めるので、 BFS の反応性が高炉セメント B 種以上に重要となる。

BFS の反応性は粉末度と化学組成により影響を受け ることが知られて抢り、JIS R 5211「高炉セメント」で は式[1]の塩基度が指標として利用されている ${ }^{6)}$ 。また、 ここでは BFS の值が 1.6 以上とされているが6)、実際 は 1.8 程度の BFS が選別されて利用されている。

$$
\left(\mathrm{CaO}+\mathrm{MgO}+\mathrm{Al}_{2} \mathrm{O}_{3}\right) / \mathrm{SiO}_{2}
$$

しかし、塩基度の高い BFS を選別して利用すること は資源有効利用の観点からは、必ずしも好ましいとはい えない。また、BFS の塩基度を高めるためには、高炉 で石灰石添加量を増加することになり、熱エネルギーが 必要であり、 $\mathrm{CO}_{2}$ 発生量の増加にもつながる可能性が 高い。BFS の活性を評価する化学組成については式[1] の JIS の塩基度ではBFS の活性を十分に評価できない として古くから多くの提案がなされている。最近の研究 でも $\mathrm{BFS}$ の活性の評価に $\mathrm{BFS}$ 中の $\mathrm{TiO}_{2}$ や $\mathrm{MnO}$ を 考慮した方が良いとの報告もなされ、下記の式 $[2]^{7)} や$ 式 $[3]^{8)}$ による改良塩基度が提案されている。また、ド イツ建材研究所は $\mathrm{TiO}_{2} 、 \mathrm{MnO}$ 抢よび可溶性 S を考慮 
Table 1 Chemical compositions of OPC and Anhydrite (mass \%)

\begin{tabular}{|l|c|c|c|c|c|c|c|c|c|c|c|c|c|c|}
\hline Samples & $\begin{array}{c}\text { Fineness } \\
\left(\mathrm{cm}^{2} / \mathrm{g}\right)\end{array}$ & ig-loss & $\mathrm{SiO}_{2}$ & $\mathrm{Al}_{2} \mathrm{O}_{3}$ & $\mathrm{Fe}_{2} \mathrm{O}_{3}$ & $\mathrm{CaO}$ & $\mathrm{MgO}$ & $\mathrm{SO}_{3}$ & $\mathrm{Na}_{2} \mathrm{O}$ & $\mathrm{K}_{2} \mathrm{O}$ & $\mathrm{TiO}_{2}$ & $\mathrm{P}_{2} \mathrm{O}_{5}$ & $\mathrm{MnO}$ & $\mathrm{Cl}$ \\
\hline OPC & 3310 & 0.93 & 20.61 & 5.13 & 3.16 & 64.27 & 1.88 & 2.2 & 0.35 & 0.35 & 0.28 & 0.61 & 0.06 & 0.015 \\
\hline Anhydrite & 3880 & 1.2 & 0.5 & 0.2 & 0.1 & 40.5 & 0.0 & 57.7 & & & & & & \\
\hline
\end{tabular}

Table 2 Chemical composition of BFS

\begin{tabular}{|c|c|c|c|c|c|c|c|c|c|c|c|c|}
\hline \multirow[b]{2}{*}{ Samples } & \multicolumn{11}{|c|}{ Chemical compositions (mass \%) } & \multirow[b]{2}{*}{ Basicity } \\
\hline & ig-loss & $\mathrm{SiO}_{2}$ & $\mathrm{Al}_{2} \mathrm{O}_{3}$ & $\mathrm{Fe}_{2} \mathrm{O}_{3}$ & $\mathrm{CaO}$ & $\mathrm{MgO}$ & $\mathrm{Na}_{2} \mathrm{O}$ & $\mathrm{K}_{2} \mathrm{O}$ & $\mathrm{TiO}_{2}$ & $\mathrm{P}_{2} \mathrm{O}_{5}$ & $\mathrm{MnO}$ & \\
\hline (1)-1 & +0.15 & 35.25 & 14.09 & 1.06 & 42.52 & 4.97 & 0.15 & 0.24 & 0.59 & 0.01 & 0.12 & 1.75 \\
\hline (1) -2 & +0.16 & 35.19 & 14.11 & 1.03 & 42.59 & 4.96 & 0.15 & 0.24 & 0.59 & 0.01 & 0.12 & 1.75 \\
\hline (1)-3 & +0.14 & 35.23 & 14.12 & 1.01 & 42.53 & 4.97 & 0.15 & 0.24 & 0.61 & 0.01 & 0.12 & 1.75 \\
\hline (2) -1 & +0.07 & 35.31 & 14.16 & 0.73 & 41.91 & 5.45 & 0.15 & 0.26 & 0.75 & 0.04 & 0.23 & 1.74 \\
\hline (2) -2 & +0.06 & 35.29 & 14.15 & 0.70 & 41.92 & 5.47 & 0.16 & 0.27 & 0.75 & 0.04 & 0.24 & 1.74 \\
\hline (2) -3 & +0.05 & 35.22 & 14.21 & 0.69 & 41.95 & 5.48 & 0.16 & 0.26 & 0.74 & 0.04 & 0.24 & 1.75 \\
\hline (3) -1 & +0.15 & 34.80 & 13.98 & 0.45 & 42.93 & 5.53 & 0.17 & 0.29 & 0.65 & 0.02 & 0.19 & 1.79 \\
\hline (3) -2 & +0.14 & 34.77 & 14.02 & 0.43 & 42.97 & 5.52 & 0.16 & 0.29 & 0.65 & 0.02 & 0.18 & 1.80 \\
\hline (3) -3 & +0.12 & 34.81 & 13.95 & 0.43 & 43.01 & 5.51 & 0.16 & 0.29 & 0.64 & 0.02 & 0.19 & 1.79 \\
\hline (4) -1 & +0.05 & 34.52 & 14.67 & 0.37 & 43.16 & 5.17 & 0.14 & 0.21 & 0.61 & 0.01 & 0.14 & 1.83 \\
\hline (4) -2 & +0.10 & 34.53 & 14.68 & 0.35 & 43.19 & 5.16 & 0.15 & 0.21 & 0.60 & 0.01 & 0.13 & 1.83 \\
\hline (4) -3 & +0.18 & 34.52 & 14.65 & 0.36 & 43.25 & 5.13 & 0.15 & 0.21 & 0.60 & 0.01 & 0.14 & 1.83 \\
\hline
\end{tabular}

した特性值 $\left(\mathrm{F}\right.$ 值) として式 $[4]^{9)}$ を提案し、2008 年から 2016 年までの 270 試料の強度特性との関連を整理し、 式[4]の妥当性を示している。

$$
\begin{gathered}
\left(\mathrm{CaO}+\mathrm{MgO}+\mathrm{Al}_{2} \mathrm{O}_{3}\right) / \mathrm{SiO}_{2}-0.13 \mathrm{TiO}_{2}-\mathrm{MnO} \\
\left(\mathrm{CaO}+0.43 \mathrm{MgO}+0.28 \mathrm{Al}_{2} \mathrm{O}_{3}\right) / \\
\mathrm{SiO}_{2}-0.46 \mathrm{TiO}_{2}-0.27 \mathrm{MnO} \\
\left(\mathrm{CaO}+0.5 \mathrm{MgO}+0.5 \mathrm{~S}^{2-}+\mathrm{Al}_{2} \mathrm{O}_{3}\right) / \\
\left(\mathrm{SiO}_{2}+\mathrm{MnO}+\mathrm{TiO}_{2}{ }^{2}\right)
\end{gathered}
$$

本研究では BFS の活性度指数や HVBFSC の初期水 和や強度に及ぼす BFS の化学組成の影響について各種 の提案されている改良塩基度の適用性も含め、工場に 扔いて製造されている BFS を用いて検討を加えた。JIS の塩基度の他に、BFS の活性度指数を示す化学組成を 用いた適切な指標を見出すことができれば、より広い範 囲の化学組成の BFS の利用につながる可能性もある。

\section{2. 実験方法}

\section{1 BFS と HVBFSC の性質}

BFS の粉末度の測定は JIS R 5201「セメントの物理 試験」BFS の化学成分の分析は JIS R 5202「セメント の化学分析方法」に準拠した。BFS の活性度指数は JIS A 6206「コンクリート用高炉スラグ微粉末」に準拠して、 材齢 7 日、28 日、91 日に执いて基準モルタル(OPC のみ)
に対する試験モルタル(OPC に BFS を 50 \% 混合)の圧 縮強さの比を求めた。

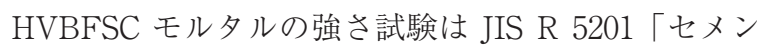
卜の物理試験方法」に準拠し、材齢 3 日、7 日、28日 での圧縮強さを求めた。HVBFSC の混合比はBFS : OPC：無水セッコウが $65: 30: 5$ mass\% で、水粉体比 は 50 \%とした。OPC と無水セッコウの化学組成と粉末 度は Table 1 に示した。

Table 2 に本試験に用いた BFS の化学組成と JIS の 塩基度を示した。(1)グループから(4)グループまで、グ ループごとに同一原料を用いて粉末度を変化させた。 従ってグループ内の BFS の化学組成は類似している。 (2)グループの $\mathrm{TiO}_{2}$ と $\mathrm{MnO}$ が他のグループに比べて大 きな值を示している。JIS の塩基度は(1)と(2)グループが 1.75 程度、(3)グループが 1.8 程度で(4)グループが 1.83 である。

\section{2 HVBFSC の水和}

HVBFSC の初期の水和特性は多点式コンダクション カロリメータにより、材齢 7 日までの熱量を測定し、 2 回の測定值の平均を求めた。また、カルシウムアルミ ネート系水和物についてはXRD により同定した。な挔、 所定の材齢で多量なアセトンにより水和を停止し、24 時間アスピレータにより乾燥させた。

\section{3. 結果と考察}

\section{1 BFS の化学組成と活性度指数}

Fig. 1 と Table 3 に本試験に用いた BFS の粉末度と 


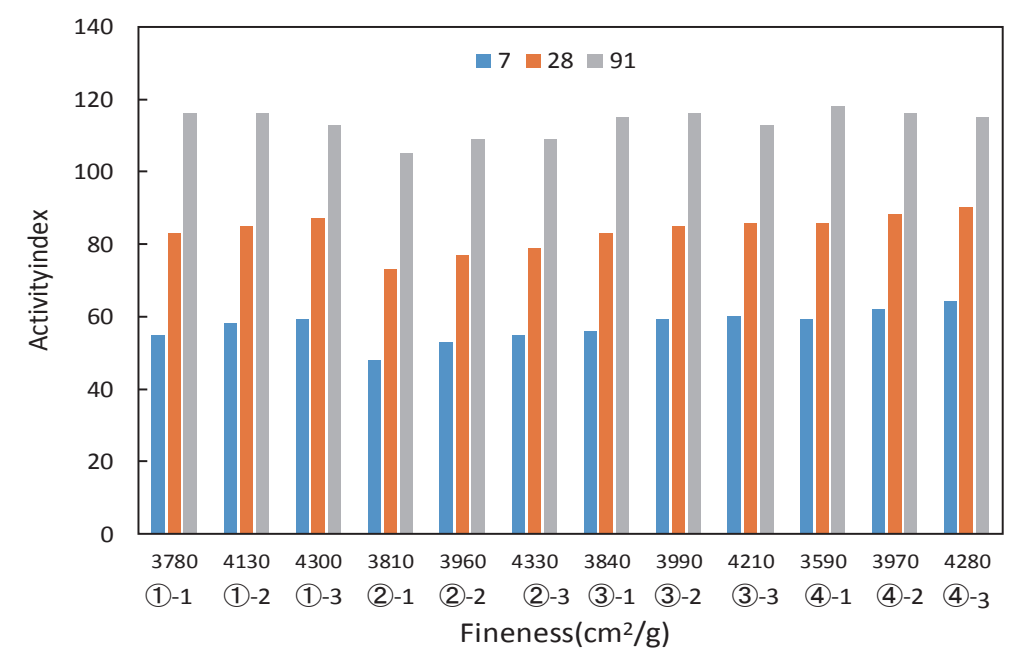

Fig. 1 Activity index of BFS

Table 3 Fineness and activity index of BFS

\begin{tabular}{|c|c|c|c|c|}
\hline & \multirow{2}{*}{$\begin{array}{c}\text { Fineness } \\
\text { Samples }\end{array}$} & \multicolumn{3}{|c|}{ Activity index } \\
\cline { 3 - 5 }$\left(\mathrm{cm}^{2} / \mathrm{g}\right)$ & $7 \mathrm{~d}$ & $28 \mathrm{~d}$ & $91 \mathrm{~d}$ \\
\hline (1)-1 & 3780 & 55 & 83 & 116 \\
\hline (1)-2 & 4130 & 58 & 85 & 116 \\
\hline (1)-3 & 4300 & 59 & 87 & 113 \\
\hline (2)-1 & 3810 & 48 & 73 & 105 \\
\hline (2)-2 & 3960 & 53 & 77 & 109 \\
\hline (2)-3 & 4330 & 55 & 79 & 109 \\
\hline (3)-1 & 3840 & 56 & 83 & 115 \\
\hline (3)-2 & 3990 & 59 & 85 & 116 \\
\hline (3)-3 & 4210 & 60 & 86 & 113 \\
\hline (4)-1 & 3590 & 59 & 86 & 118 \\
\hline (4)-2 & 3970 & 62 & 88 & 116 \\
\hline (4)-3 & 4280 & 64 & 90 & 115 \\
\hline
\end{tabular}

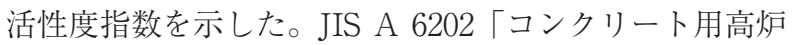
スラグ微粉末」 ${ }^{10)}$ の BFS4000 の規格では、BFS の粉末 度は 3500 以上 $5000 \mathrm{~cm}^{2} / \mathrm{g}$ 未満で、活性度指数は材齢 7 日で 55 以上、材齢 28 日で 75 以上、材齢 91 日 95 以上となっている。粉末度はいずれも JIS の規格の範 囲である。(2)グループの材齢 7 日と(2)-1 の材齢 28 日は、 活性度指数の JIS の規格を満足していないが、他のす べての試料と材齢で活性度指数の JIS の規格值を満足 している。

(1)グループは同一の BFS を用いて、(1)-1 から (1)-2 および(1)-3 へと粉末度を大きくしている。(2)、(3)よ び(4)グループについても同様である。(1)、(3)よび(4)グ ループについては、材齢 7 日、28 日、91 日とあまり大 きな差ははなく、JIS の規格值より大きな活性度指数を 示した。また、材齢 7 日と 28 日では、各グループ内で は粉末度の大きい方が BFS の活性度指数は大きな值を 示した。材齢 91 日では粉末度の影響は小さい。これは 初期での BFS の反応が活発となり長期での反応が抑制
Table 4 Modified basicity of BFS

\begin{tabular}{|c|c|c|c|}
\hline Samples & Eq.[2] & Eq.[3] & $\begin{array}{c}\text { Eq.[4] } \\
\text { F-value }\end{array}$ \\
\hline (1)-1 & 1.55 & 1.27 & 1.67 \\
\hline (1)-2 & 1.55 & 1.27 & 1.67 \\
\hline (1)-3 & 1.55 & 1.27 & 1.67 \\
\hline (2) -1 & 1.41 & 1.21 & 1.64 \\
\hline (2)-2 & 1.40 & 1.21 & 1.64 \\
\hline (2) -3 & 1.41 & 1.21 & 1.65 \\
\hline (3)-1 & 1.52 & 1.28 & 1.70 \\
\hline (3)-2 & 1.54 & 1.28 & 1.70 \\
\hline (3)-3 & 1.52 & 1.28 & 1.70 \\
\hline (4)-1 & 1.61 & 1.32 & 1.74 \\
\hline (4)-2 & 1.62 & 1.32 & 1.74 \\
\hline
\end{tabular}

されるためと考えられる。

一方(2)グループについては、JIS の塩基度は(1)グルー プと同等であるものの、活性度指数は(1)グループより小 さい值を示した。

(2)グループについて、(2)-2 と(2)-3 では(2)-1 より粉 末度をそれぞれ $150 \mathrm{~cm}^{2} / \mathrm{g}$ と $520 \mathrm{~cm}^{2} / \mathrm{g}$ 増加している。 これにより(2)グループの活性度指数は増加するが、材齢 7 日、28 日拈よ゙ 91 日で(1)、(3)よび(4)グループより 低い值を示している。JIS A 6202 「ンクリート用高炉 スラグ微粉末」10)の BFS4000 の規格では、BFSの粉末 度は 3500 以上 $5000 \mathrm{~cm}^{2} / \mathrm{g}$ 未満であり、JI S の規格内 での(2)-3 のように粉末度を 4300 程度と増大できるが、 (2)-3 でも (1)、(3)および(4)グループと活性度指数を同等 とすることはできない。

Table 4 に $\mathrm{TiO}_{2}$ と $\mathrm{MnO}$ を考慮した式[2]と式[3]お よび式 [4]により求めた BFS の改良塩基度を示した。 各試料の改良塩基度は式[2]で 1.41～1.62、式[3]が 1.21 ～1.32、式[4]の場合は 1.65１.74の範囲である。い 
Table 5 Modifed basicity and activity index of BFS

\begin{tabular}{|c|c|c|c|c|c|c|c|c|}
\hline Samples & $\begin{array}{c}\text { Fineness } \\
\left(\mathrm{cm}^{2} / \mathrm{g}\right)\end{array}$ & $\begin{array}{c}\text { Basicity } \\
\text { (JIS) }\end{array}$ & Eq.[2] & Eq.[3] & $\begin{array}{c}\text { Eq.[4] } \\
\text { F-value }\end{array}$ & AI(7d) & AI(28d) & AI(91d) \\
\hline (1)-3 & 4300 & 1.75 & 1.55 & 1.27 & 1.67 & 59 & 87 & 113 \\
\hline (2)-3 & 4330 & 1.75 & 1.41 & 1.21 & 1.65 & 55 & 79 & 109 \\
\hline (3)-3 & 4210 & 1.79 & 1.52 & 1.28 & 1.70 & 60 & 86 & 113 \\
\hline (4)-3 & 4280 & 1.83 & 1.61 & 1.32 & 1.74 & 64 & 90 & 115 \\
\hline
\end{tabular}

(AI : Activity index)

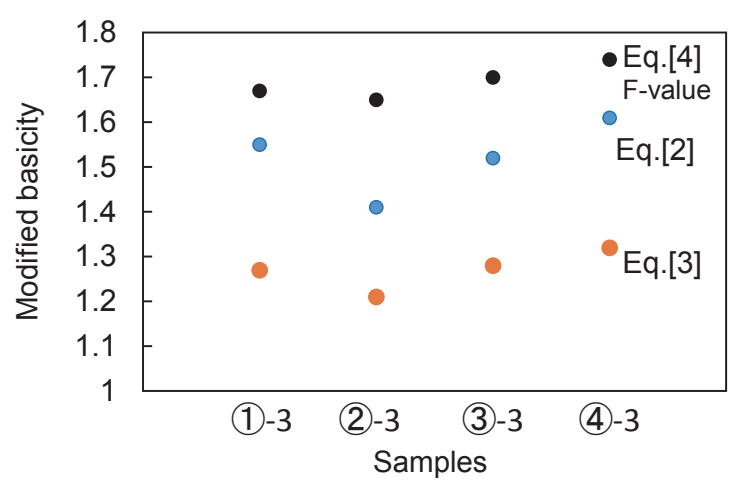

Fig. 2 Modified basicity of BFS

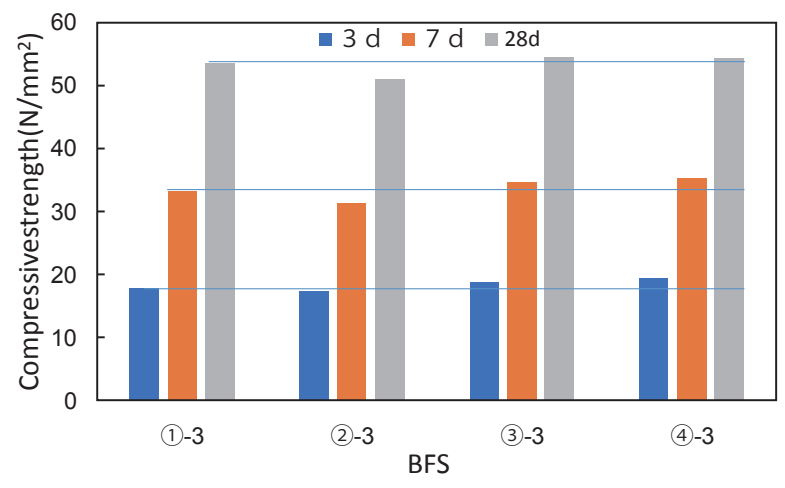

Fig. 4 Compressive strength of HVBFSC mortar

ずれの場合も各改良塩基度において、グループ(2)が他の 場合より小さな值を示した。

粉末度が異なる試料においてもグループ内の改良塩基 度の值はほぼ等しいので各グループの粉末度 4300 程度 のものにおいて、Table 5 に $\mathrm{TiO}_{2}$ と $\mathrm{MnO}$ を考慮した 改良塩基度と活性度指数を示した。(1)と(2)グループの JIS 塩基度はほとんど等しいが、 $\mathrm{TiO}_{2}$ と $\mathrm{MnO}$ を考慮 した式[2]と式[3]抽゙[4]では、(2)グループが他のも のより塩基度は小さくなっている。式[2]と式[3]および 式[4]のどちらの改良塩基度を用いても、(2)-3の活性度 指数が他より低いことと(3)や(4)グループの活性度指数が 高いことを判別することは可能である。なお、JIS の規 格の範囲で粉末度を増加しても(2)-3 の活性度指数を他 のものと同程度とすることは難しい。

Fig. 2 に(1)-3、(2)-3、(3)-3 および(4)-3 の改良塩基度 を示した。それぞれの数值は異なるが傾向は一致して

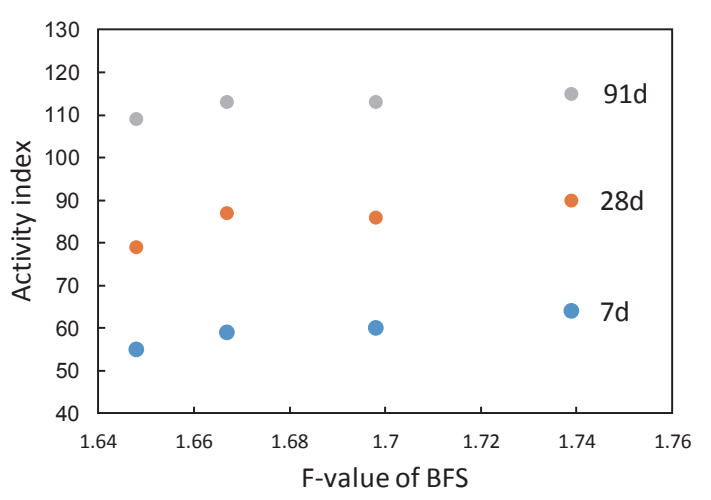

Fig. 3 Relation between activity index and F-value of BFS

おり、(2)-3 が他の場合より小さい。グループ内では他 の場合より (2)-3 が式[4]の F 值に比べて、式[2]および 式[3]の值が小さい。式[2]と式[3]においては、式[4]よ り $\mathrm{BFS}$ の化学組成中の $\mathrm{TiO}_{2}$ と $\mathrm{MnO}$ の改良塩基度へ の影響が大きく表われる。

BFS の (1)-3、(2)-3、(3)-3 および(4)-3 の粉末度がそ れぞれ 4300、4330、4210 および $4280 \mathrm{~cm}^{2} / \mathrm{g}$ とほぼ等 しい場合の改良塩基度の一例として $\mathrm{F}$ 值と活性度指数 の関係を Fig. 3 に示した。他の改良塩基度でも同様の 傾向を示す。F 值が 1.65 の BFS の活性度指数が各材 齢で他の場合より低い。粉末度が等しい場合に $\mathrm{TiO}_{2}$ や $\mathrm{MnO}$ を考慮した $\mathrm{F}$ 值は活性度の評価として利用可能 であることを示している。また、活性度の低い BFS を 選別するという意味では、式[2]や式[3]あるいは式[4] の $\mathrm{F}$ 值でも評価が可能となっている。なお、F 值の 算出には BFS 中の可溶性の $\mathrm{S}^{2-}$ が必要であるが、こ こでは Total S(T.S)を用いた。(1)から(4)の T.S は(1)が 0.86 mass\%、(2)が 0.83 mass\%、(3)は 0.85 mass\%およ

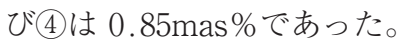

Fig. 4 に HVBFSC モルタルの圧縮強さを示した。粉 末度のほぼ等しい BFS を用いた場合の圧縮強さであ る。いずれの材齢でも圧縮強さは、(2)-3 が他のものよ り低い值を示したが、それ以外はほぼ同様な值を示した。 Fig. 2 に示したように(2)-3 の改良塩基度は他のものよ り低い。改良塩基度の低いBFS を用いると HVBFSC のモルタル強度も低い。粉末度を 4300 程度とした場合

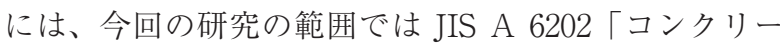




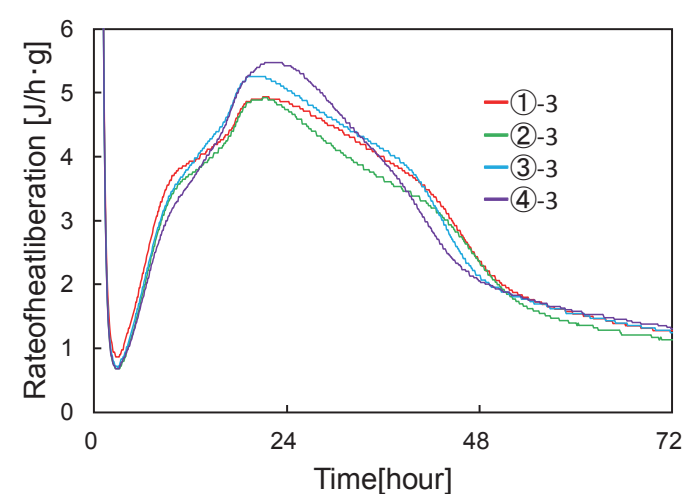

Fig. 5 Rate of heat liberation of HVBFSC
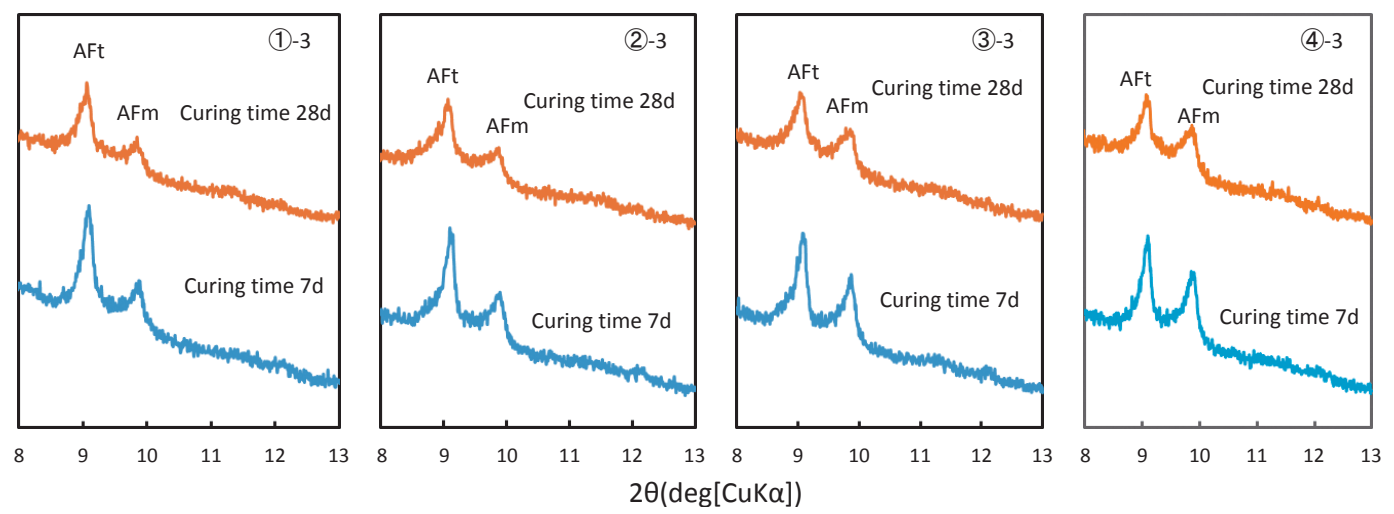

Fig. 7 XRD patterns of calcium aluminate hydrates in hydrated HVBFSC

ト用高炉スラグ微粉末」10) の BFS4000 の規格を満足し ているので、改良塩基度の使用可能な下限值の提案には 至っていない。

なお、F 值については、既に述べたようにドイッの Institute fur Baustoff Forschung Institute fur Baustoff Forschung において、実際に利用されているBFS を用 いた高炉セメントの強度発現性と式 [4]の F 值との関係 を長年にわたり求めている。式[2]や式[3]の改良塩基度 についても同様なデー夕蓄積が望まれる。

\section{2 HVBFSC の水和}

Fig. 5 はコンダクションカロリメータにより測定した HVBFSC の発熱速度曲線である。各グループで粉末度 のほぼ等しい(1)-3、(2)-3、(3)-3 および(4)-3 の BFS を 用いた場合を示した。他の試料の場合もほぼ同様の発 熱速度曲線を示す。なお、HVBFSC の組成はBFS： $\mathrm{OPC}$ ：無水セッコウが $65: 30: 5 \mathrm{mass} \%$ とし、水粉体 比は $50 \%$ とした。これらは HVBFSC の初期水和特性 と関連する。11 時間程度の最初のピークが OPC の水 和に基づき、 2 番目の 20〜23 時間程度のピークが $\mathrm{BFS}$ の反応に基づくと考えることができる。また、40 時間 程度と 50 時間以後のピークも BFS の反応によると考 えることができる。(3)-3 と(4)-3 は 2 番目のピークが大 きくなっており BFS の反応も活発になっている。(1)-3 と (2)-3 を比べると第二ピークには大きな差はないが、

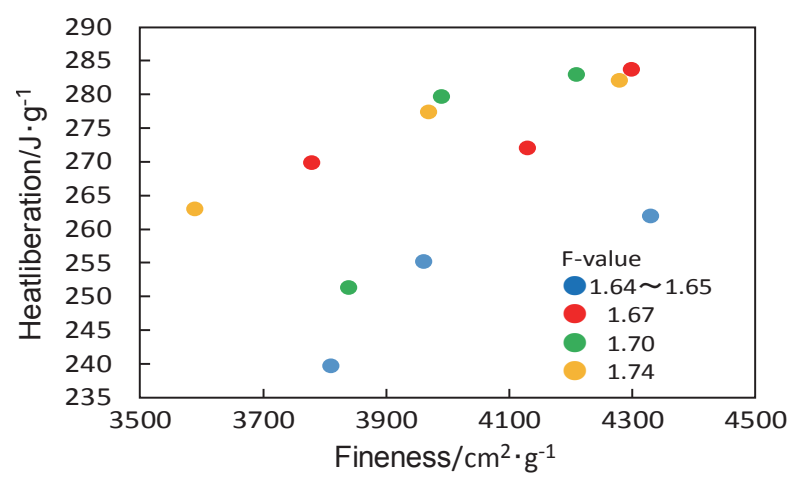

Fig. 6 Heat liberation of HVBFSC
その後の 40 時間や 50 時間以後の反応が(2)-3 は抑制さ れている。Fig. 6 に材齢 7 日までの HVBFSC の初期 水和発熱量と BFS の粉末度と改良塩基度の一例として 式[4]の F 值の関係を示した。材齢 7 日までの初期水 和は、BFS の粉末度が大きくなるほど水和発熱量が増 加し水和が進んでいる。しかし、F 值が 1.64 1.65 と 1.67〜1.74の BFS で異なる関係を示している。これは $\mathrm{F}$ 值が 1.65 程度以下の BFS を用いた HVBFSC の水 和特性が劣っていることを表しており、F 值と粉末度に より BFS を選定すれば、HVBFSC の初期水和特性を 評価できるものと考えられる。なお、F 值が 1.7 で粉 末度 3840 の BFSのみ傾向が異なっている点については、 さらに詳細な検討が必要である。

コンダクションカロリメータによる水和熱から BFS の HHVBFSC の強度への影響を評価できる。今回の研 究の範囲では、式 $[2]$ 、式 $[3]$ および式 $[4]$ の改良塩基度 が 1.52、1.27 および 1.66 以上の BFS を選定して、さ らに粉末度 4000 程度のものを選べば、HVBFSC の強 度は同様な傾向を示すと予想することができる。

Fig. 7 に材齢 7 日と 28 日における HVBFSC の水 和により生成したカルシウムアルミネート系水和物の $\mathrm{XRD}$ パターンを示した。BFS としては化学組成が異な る(1)、(2)、(3)およ゙(4)グループから粉末度が 4300 程度 の (1)-3、(2)-3、(3)-3 および(4)-3 の BFS を用いた。カ 
ルシウムアルミネート水和物の生成は、セッコウ添加 量がいずれも等しいので BFS の反応量と関連する。い ずれの場合も材齢 7 日と 28 日で $\mathrm{AFt}$ と AFm が生成 している。(2)-3では他の場合に比べて、材齢 7 日と 28 日とも AFt のピークが大きく、AFmのピークが小さい。 (1)-3でも AFtのピークが大きい。これに対して(3)-3 や(4)-3 の BFS を用いた場合には、他の場合より AFm のピークが大きくなっている。これは BFS の反応量が 多いと生成物中の $\mathrm{SO}_{3} / \mathrm{Al}_{2} \mathrm{O}_{3}$ 比が低下し、 $\mathrm{AFm}$ の生成 が増大すると考えられる。BFS の F 值が Table 5 から (1)-3 は 1.67、(2)-3 は 1.65、(3)-3 は 1.70、(4)-3 は 1.74 であり、(1)-3 と(2)-3 は近く、(3)-3 と (4)-3 は近い值を 示し、生成物の傾向と一致している。

\section{4. 結論}

高炉スラグ高含有セメント (HVBFSC) の水和や強度 に及ぼす高炉スラグ微粉末 $(\mathrm{BFS})$ の化学組成や粉末度の 影響について検討した。本研究の範囲で得られた結論は 以下の通りである。

（1）BFS の化学組成が活性度指数に及ぼす影響が大き く、また、JISの規格内で粉末度の増加により補え る範囲に限界もある。

(2) JIS 塩基度はほぼ等しい BFS でも活性度指数は異 なるものがある。

（3）HVBFSC の水和と強度に及ぼす BFS の影響は、F 值も含め $\mathrm{TiO}_{2}$ と $\mathrm{MnO}$ を考慮した改良塩基度と粉 末度による評価により可能である。

（4）HVBFSC の初期水和生成物としてはエトリンガイ ト $(\mathrm{AFt})$ とモノサルフェート $(\mathrm{AFm})$ が生成するが、 セッコウ添加量が等しい場合には、活性度の高い $\mathrm{BFS}$ を利用すると $\mathrm{AFm}$ の生成が増加する。
謝辞 :

本研究は日本スラグセメント・コンクリート技術研究 会の活動の一環として実施したもので、また、本研究の 一部は鐵鋼スラグ協会の援助によった。関係各位に感謝 致します。

\section{参考文献：}

1) M. Schneider : The cement on the way a low carbon future, Cement \& Concrete Res., Vol. 124, 105792 (2019)

2）坂井悦郎ほか：初期水和性状を考慮した高炉スラグ 高含有セメントの材料設計、セメント・コンクリー 卜論文集、No. 65、pp. 20-26（2011）

3）坂井悦郎ほか：高炬スラグ高含有セメントの水和に 及ぼす養生温度の影響、セメント・コンクリート論 文集、Vol. 70、pp. 119-126（2016）

4）坂井悦郎ほか：亜硝酸カルシウムを添加した高炬ス ラグ高含有セメントの水和、セメント・コンクリー 卜論文集、Vol. 71、pp. 62-67（2017）

5）坂井悦郎ほか：高炬スラグ高含有セメントの水和 に及ぼす亜硝酸カルシウムとアルカノールアミン の影響、セメント・コンクリート論文集、Vol. 73、 pp. 52-58 (2019)

6） JIS R 5211「高炉セメント」

7）當房博幸ほか：高炉スラグ微粉末の活性度に及ぼす $\mathrm{MnO}$ の影響、JFE 技報、No. 40、pp. 75-79（2017）

8）伊藤貴康ほか： $\mathrm{CaO}-\mathrm{Al}_{2} \mathrm{O}_{3}-\mathrm{SiO}_{2}-\mathrm{MgO}$ 系スラグの 活性度指数に及ぼす化学成分の影響、セメント・コ ンクリート論文集、Vol. 70、pp. 222-229（2016）

9) Research Projects from Recent Years. Institute fur Baustoff Forschung, p. 3

10）JIS A 6202 「ンクリート用高炉スラグ微粉末」 


\title{
INFLUENCES OF CHEMICAL COMPOSITIONS AND FINENESS OF BLAST FURNACE SLAG ON STRENGTH AND HYDRATION OF HIGH VOLUME BLAST FURNACE SLAG CEMENT
}

\author{
Nobukazu NITO*1, Yukiko UEDA*2, Kazuki MATSUZAWA*2 and Etsuo SAKAI*2 \\ *1 DC CO., Ltd., Technical Center (1-17, Asano-cho, Kawasaki-ku, Kawasaki-shi, Kanagawa 210- \\ 0854, Japan) \\ *2 TOKYO Institute of TEChNOlogy, Graduate School of Materials and Chemical \\ Technology (2-12-1, Ookayama, Meguro-ku, Tokyo 152-8552, Japan)
}

\begin{abstract}
This paper describes the influences of chemical composition and fineness of granurated blast furnce slag (BFS) on the hydration and strength of high volume blast furnace slag cement (HVBFSC). Chemical compositon of BFS is mainly influenced on the strength of HVBFSC and activity index of BFS. It is difficult that the increase fineness of BFS having lower basicity can be improved on the activity index of BFS and hydration of HVBFSC. The same JIS basicity of BFS shows the different activity index of BFS and hydration properties of HVBFSC. The basicity of BFS considering $\mathrm{TiO}_{2}$ and $\mathrm{MnO}$ can be selected the lower activity index of BFS and the hydration of HVBFSC. In early hydration of HVBFSC, AFt is mainly produced, But the formation of AFm is increased in the case of HVBFSC containing higher activity BFS.
\end{abstract}

KEY WORDS : High volume blast furnace slag cement, Activity index, Hydration, Chemical composition, Finenes, Basicity, $\mathrm{TiO}_{2}, \mathrm{MnO}$ 